\title{
ARCHITECTURAL PATRIMONY IN THE GRAPHICAL REPRESENTATION OF THE VOISIN PLAN
}

\author{
Victor VELASQUEZ \\ Architecture Faculty, Universidad Nacional de Colombia, Carrera $45 N^{\circ} 26-85$, Bogotá, Colombia \\ E-mail:vhvelasquezh@unal.edu.co
}

Received 15 November 2015; accepted 04 March 2016

\begin{abstract}
The "Plan Voisin" for Paris dated 1925, is one of the most notorious urban projects by Le Corbusier. In it he implements his first real model of the modern city: "The city of Three Million Inhabitants", drawn for the Autumn Exhibit on 1922. Both projects have a close and direct relation. While one proposes a theoretical model, the other develops how to implement it in the center of Paris. Therefore, both projects can be understood as the same approach but in two different moments. In Le Corbusier's books, the graphical representation of the projects reflect this, although the documents tend to contradict it. In his "CEuvre complète", for example, the number of images differs for each case. While the project "The city of three million Inhabitants" is represented by a generous amount of drawings and plans (around 20 images), the "Plan Voisin" adds up to a maximum of five specific images. In the book "Urbanisme" the proportion is of images is similar. This This is a cause of scarce comprehension of the plan for Paris. The article focuses on the graphical documentation in "Plan Voisin", its difference with the theoretical model and an analysis of its implementation. Principally, the article studies the relation between the new buildings with with those that remains, revealing Le Corbusier's criteria towards architectural heritage and the importance he gives to some urban complexes in Paris.
\end{abstract}

Keywords: architecture of public buildings, cultural heritage, Plan Voisin, drawings, planning, architectural documentation, graphical representation.

\section{Introduction}

Because of its significance and radicalism of the proposal the Voisin Plan of Le Corbusier for Paris produces a strong visual impact onthe off-guard observer. The plan outlines the establishment of a novel system of buildings while eliminating an important fragment of the city's layout, but apparently includes all its existing architecture. Since Le Corbusier presented it in 1925, he is rejected and criticized for his idea and even considered barbaric by some critics (Le Corbusier 1933: 13). In time, the project becomes an icon of the modern city (see Rowe, Koetter 1978: 69, 76-77), and also embodies one of its major flaws: his apparent lack of sensitivity towards the historic city (see von Moos 2009: 222). Independently of any judgment, it is indeed of great importance of the proposal regarding the maturation process towards a new way of facing urban problems. The study of the buildings in the Plan Voisin with respect to those that remain might reveal an idea of patrimony in Le Corbusier and the value that he gives to some architectonic examples and urban compounds of this sector of Paris. The doc- uments that illustrate the project and its representation system must, therefore, be carefully studied, but before, some of the ideas which originated the Plan, developed some years before, should also be reviewed.

\section{The version of the Salon d'Automne, 1922}

In 1922, Le Corbusier is invited to take part in the Salon d'Automne in Paris where he exhibits the first of his great urban proposals: "The Contemporary city for three million inhabitants". The exhibition would mark a crucial moment in his work: the beginning of the diffusion of his urban planning ideas. Though the theoretical city does not have a concrete site, its configuration does respond to some very precise criteria. The project of the city is developed from three different and complementary angles: the dwelling cell, the architectural compound and the urban plan. The house (primary seed), the building and the city as samples of a comprehensive proposal, a common project, are an ambitious attempt to tackle the problem in its entirety. The outline responds to a clear geometric model: 
a huge rectangle with a clearly defined center, determinant point, and the orthogonal intersection of two grand roads (Fig. 1). In spite of its vast dimensions, the city is organized with just three types of buildings: the cruciform skyscraper, the closed compound (Immeuble-Villas) and the buildings in redents. Each of these types of buildings will become the true standards of his architectonic and urban development that will require years of research for Le Corbusier. On one side the compound of isolated vertical buildings and the cruciform skyscrapers constitute the geometric business centers of the city. The other two establish great residential sectors. The Immeuble-Villas tends to be located in the outskirts of the city while the entire intermediate zone is reserved for the buildings in redents. The orthogonal grid is interrupted by the diagonals at $45^{\circ}$ that mark and contrast with the great rectangle of the city. The scheme of the city is completed with some facilities buildings, a huge area of vegetal reserve, the suburban zones of a garden city and an industrial zone plowed through by a hypothetical river.

The exhibition of the Salon d'Automne of 1922 marks a transcendental moment of synthesis for Le Corbusier that will transcend and opens new paths. From here, future developments emerge. They will become real in new projects. He even refers to the surprising results of the experiment.

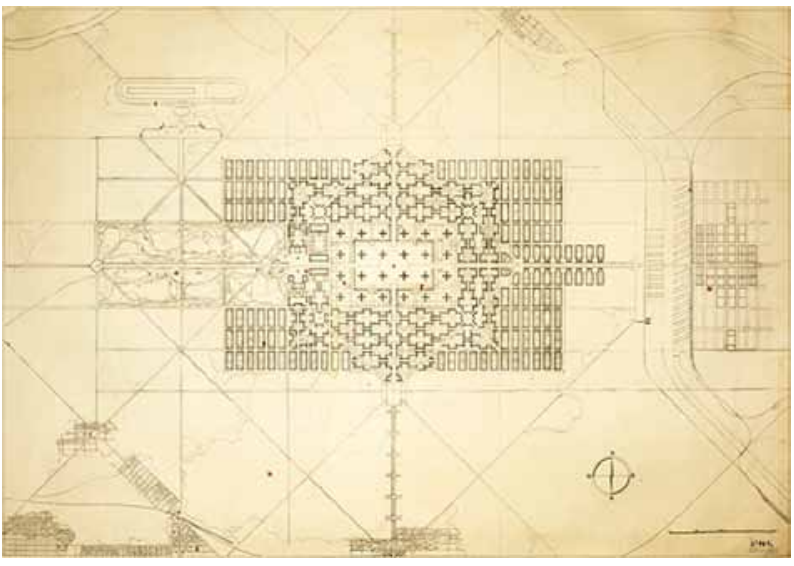

Fig. 1. Plan of Contemporary City for Three Million Inhabitants. FLC31006 @ FLC-ADAGP
"Through this study we penetrate in the miraculous world of imminent certainties. The analysis led to dimensions, new scales and the synthesis to an urban organism so different to what exists that it is difficult for the spirit to imagine it" (Le Corbusier, Jeanneret 1929: 34).

The complexity of the proposal, coming from a high degree of interdependence among the three scales and its varied level of development, implies a real challenge with respect to its architectonical representation. The hard work is assumed almost in solitary by Le Corbusier and his cousin Pierre Jeanneret. The architects express their ideas in several graphic documents: A huge floor plan of the city (Fig. 1, FLC31006), a set of explanatory schemes, three perspective drawings that illustrate different areas of the proposal (Fig. 2, FLC30828) and a huge panoramic image, which Le Corbusier calls "Diorama" (Fig. 3, FLC L3-20-2-4).

The plans and the model of the Citrohan House, the floor plans and an exterior perspective drawing of the Immeuble-Villa are added to these documents. Maybe due to the great challenge, that from a graphic perspective, the representation of the city implies, this amount of documents are only accompanied by a brief and plain written explanation. This lack of balance between the graphic and the explanatory text generates a great effect

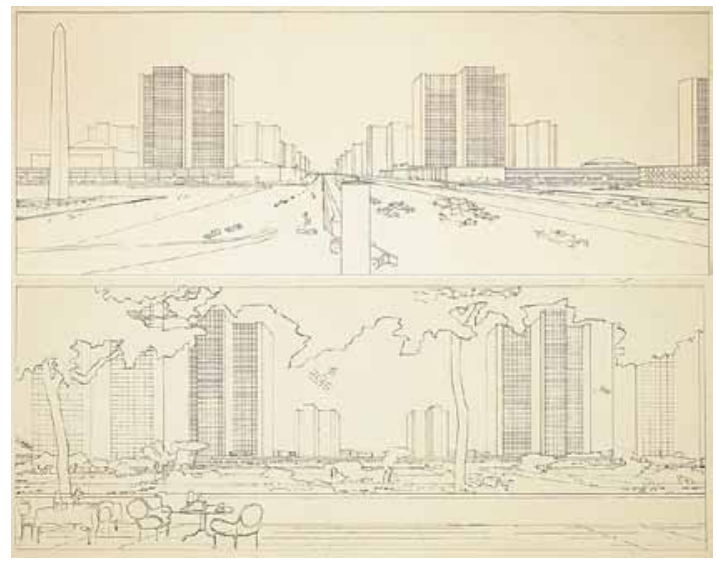

Fig. 2. Perspective views of Contemporary City for Three Million Inhabitants. FLC30828 @ FLC-ADAGP

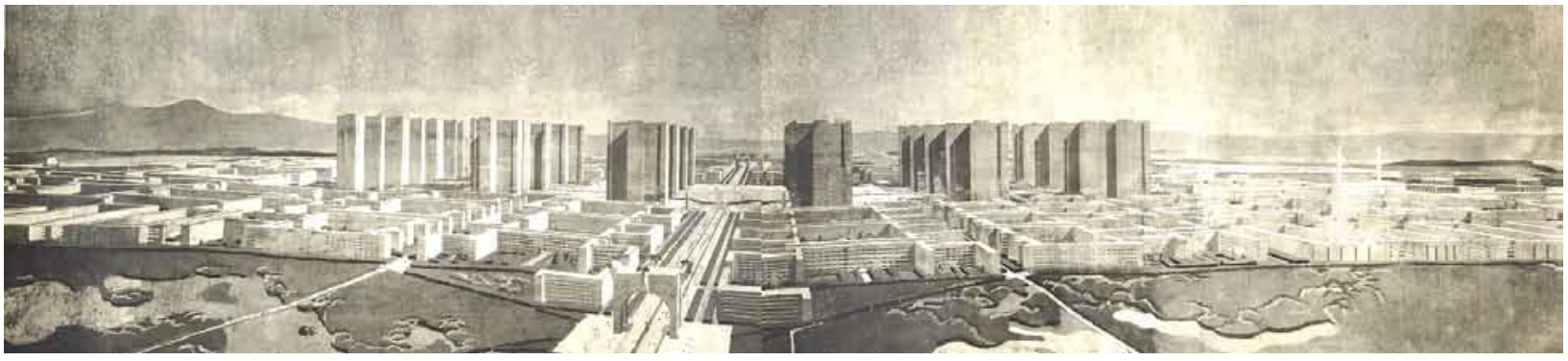

Fig. 3. Diorama of Contemporary City for Three Million Inhabitants. L3-20-(2-4) ๑ FLC-ADAGP 
in the media, evidences the forcefulness of the images. The City for Three Million Inhabitants becomes a great platform of dissemination for Le Corbusier. It projects his name not only in the French setting, but also internationally (see Velásquez 2012: 225).

\section{The step from the theoretical model to the precise case of Paris}

Once the 1922 exhibition finishes, Le Corbusier continues working decidedly in the lines sketched there. Towards the end of the year he finishes writing the book Vers une architecture and turns to writing Urbanisme, a book that will try to fill in the gap left by the lack of an explanatory text during the occasion. In the June edition of the l'Esprit Nouveau review he publishes "Le chemin de ânes, le chemin des homes" that will become the first chapter of the book, and in the following numbers (November and December) two other chapters. Everything searched for, that began there, will provide architects the opportunity to develop specific project tasks. They pick up specifically the points that have been left open: the details of the cell, its grouping in the Immeuble-Villa (Fig. 4) and in the buildings in redents, the evolution of the cruciform skyscraper, the relationship of the building systems with the public space and green zones. A clear horizon appears with the announcement of the international Exhibition of Decorative Arts to take place in 1925, when new drawings would be finished (Fig. 5).

In Urbanisme, Le Corbusier insistently points out that the real difficulties of the contemporary city are identified and stressed in its center. Traffic jams, chaos, inefficiency, and therefore, the real problem is there:

"Alas, we have become like the rusty engine of some out-of-date motorcar; the chassis, the body, the seats (the peripheries of our cities) can carry on still, but the motor (the center) is seized! This means complete breakdown. The centers of the great cities are like an

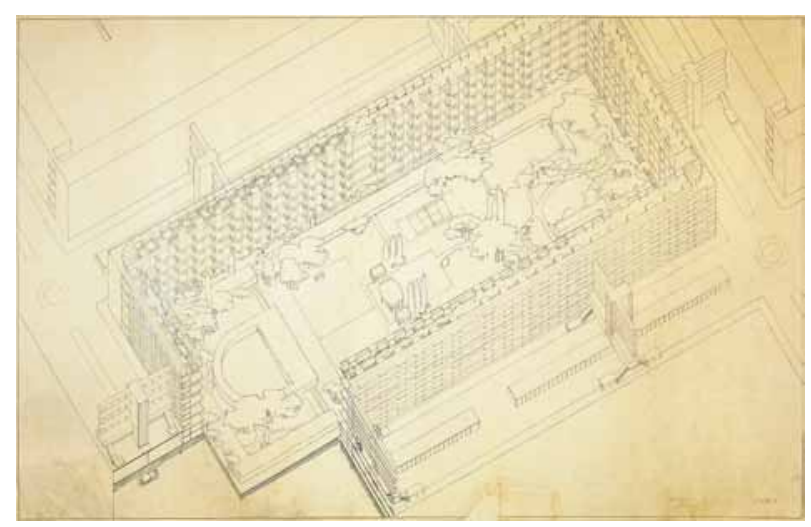

Fig. 4. Axonometric view of Immeubles-villa 1925. FLC30849 (c) FLC-ADAGP

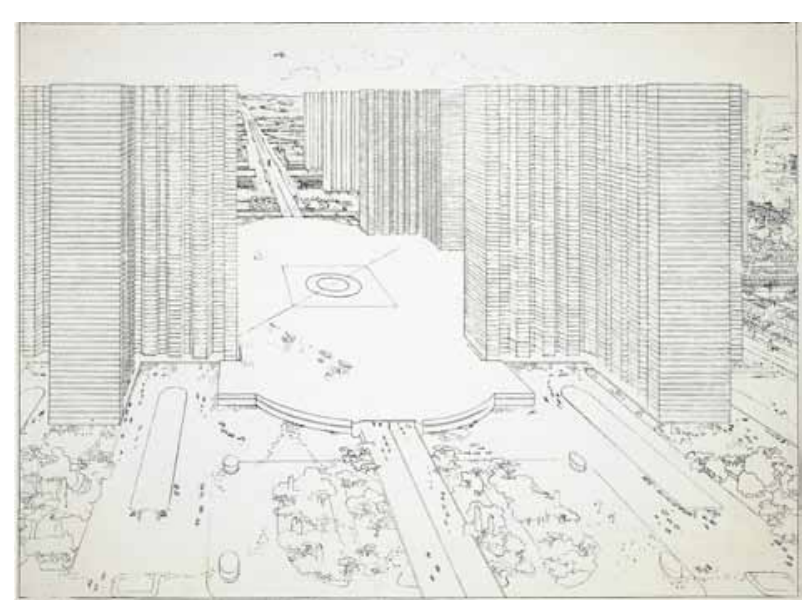

Fig. 5. New view of Contemporary City for Three Million Inhabitants drawn in 1925. FLC30850 @ FLC-ADAGP

engine which is seized. Here we have the very first problem of town planning". (Le Corbusier 1925: 87)

It is not strange that in order to prove the model of a city, not yet explained enough, and to illustrate its relevance, Le Corbusier choses then, the most paradigmatic case, the city that has welcomed him recently and that additionally he has been studying carefully: Paris. The topics addressed in the city of Three Million Inhabitants (the laboratory work) will gain new momentum and will be explained more explicitly thanks to its application to the exact case of the Paris center. The Voisin Plan emerges.

However, implementing the theoretical model clashes with a concrete reality: the pre-existences of the city and its history. Le Corbusier does not see this circumstance as a motive to be intimidated, but, on the contrary the opportunity to act according to a didactic and advertising strategy:

"We hesitate to admit the truth to ourselves; we have not the courage to diagnose the disease and recognize it, and to take the necessary bold measures to deal with it." (Le Corbusier 1925: 87).

The problem has to be faced with courage. Great solutions are given to great problems. Surgery is better than palliative medicines (See Le Corbusier 1925). The example can only be one that calls for the will of people and the most sensitivity to react. Le Corbusier selects a wide sector of the heart of the city to develop his project

Implementing the model will follow a pattern according to which must, in the first place, define two main sectors: the business center and a residential zone. Between the two, he suggests a central underground station. This intermediate point is located in the Palais Royal zone and from there the entire plan spreads out.

The business center (Sector A), on the east side of the station, comprises a zone that extends from Place de la République to Rue du Louvre and from Gare de 


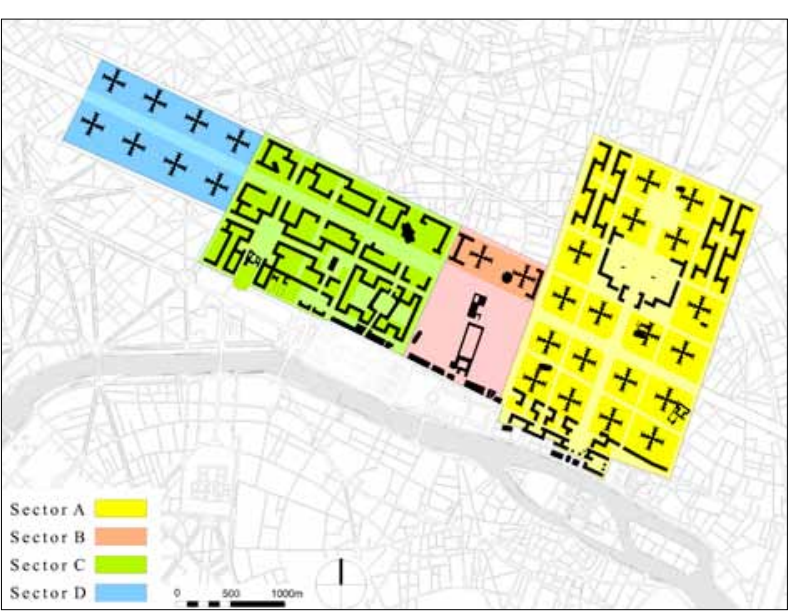

Fig. 6. Sectors of Plan Voisin

l'Est to Rue de Rivoli. There, eighteen (18) cruciform skyscrapers stand out in the midst of a series of buildings in redents.

The residential zone (Sector C) extends from Rue des Pyramides up to the round-point of Champs Elysées (currently the intersection Avenue Franklin D. Roosevelt) and from Gare Saint-Lazare up to Rue de Rivoli. These are almost entirely inhabited by buildings in redents.

The central station (Sector B) ends with two cruciform skyscrapers. Le Corbusier does not mention it, but, there is a fourth area (Sector D) drawn in different documents that goes from the western limit of the residential area to Wagram avenue where he locates again eight (8) new cruciform towers (Fig. 6).

The four zones are intertwined by a really prominent road axis that is lost within the limits of the floor plan crossing the city from east to west. According to Le Corbusier, this great 120 meters wide artery, with an elevated highway and parallel to Champs Elysées, to relieve overcrowding in the downtown of the city, interconnect two external points of its perimeter belt, from Vincennes Quartier to Levallois-Perret. From the plan, other spacious roads in north-south direction, particularly the one that crosses a great esplanade in the business center emerge.

The fragment of the city covered by the plan is of considerable dimensions. It adds up to 571 hectares ( 250 for the business center, 85 for the central station, 158 for the residential zone and 78 more for the fourth sector). The project partially affects up to seven different administrative districts (arrondissements). The demolished neighborhoods, however, have not been chosen randomly. For Le Corbusier "this plan considers the most infectious neighborhoods, the narrowest streets" [...] "neighborhoods mostly oversaturated and covered by middle class houses that currently serve as offices." (Le Corbusier 1925: 264, 266).
It is easy to conclude that Le Corbusier considers all the zone as a tabula rasa. However, the plan does not require to totally demolish the architecture of this vast sector of Paris, as shown in the detailed plans of the Plan, done for the occasion of the Decorative Arts Exhibition of 1925, and of some parts of his book Urbanisme.

\section{The drawings done for the 1925 Exhibition}

As already seen, the relationship of continuity between the city for Three Million Inhabitants and the Voisin Plan is close and direct. Because of this, sometimes documents on the two projects tend to get confused. However, the number of graphics is different for each case. In the Euvre Complète, for example, while the city for Three Million Inhabitants its presented through a generous series of drawings and plans (around 20 images), for the Voisin Plan there are barely around five specific images. To those drawings done in 1925, a floor plan is added specially to represent the Plan in the book Urbanisme. The graphic documents are: a general floor plan (Fig. 7), a more detailed floor plan of a fragment of the business center (Fig. 8), an axonometric projection of the same fragment (Fig. 9), a panoramic image of the entire plan to be exhibited in the diorama (Fig. 10) and finally, an aerial perspective view (Fig. 11). A model of large dimensions done towards 1929 is also added. There is quite scarce material to be able to locate clearly the pieces of the city that are maintained. This has somehow favored an insufficient understanding of the Plan.

The general floor plan (Fig. 7) in spite of being general is the one, which contains the best information on what buildings were preserved. The color version (Fig. 12) published in Urbanisme and in an article of the Science et Industrie magazine of 1926 is especially rich in information.

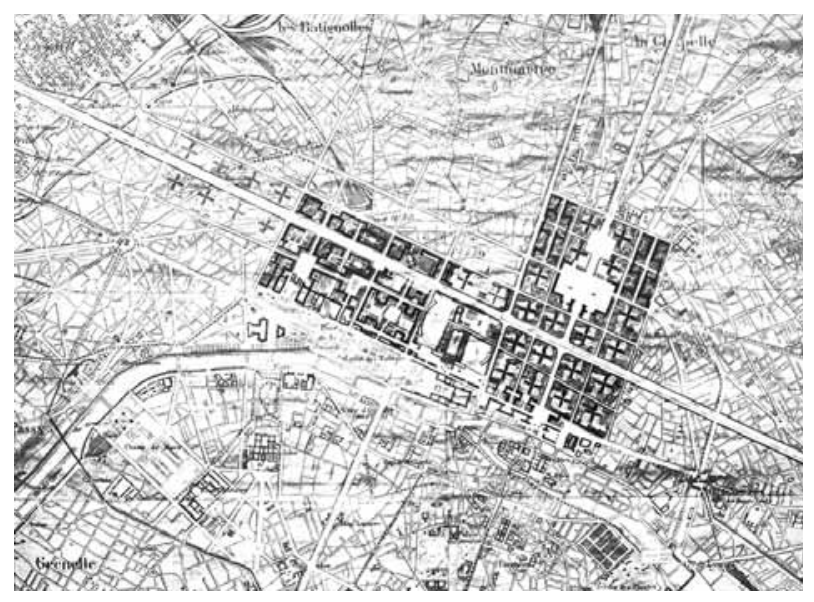

Fig. 7. General floor plan of Plan Voisin. Version published in Gesamtes Werk 1929, p. 111 ๑ FLC-ADAGP 

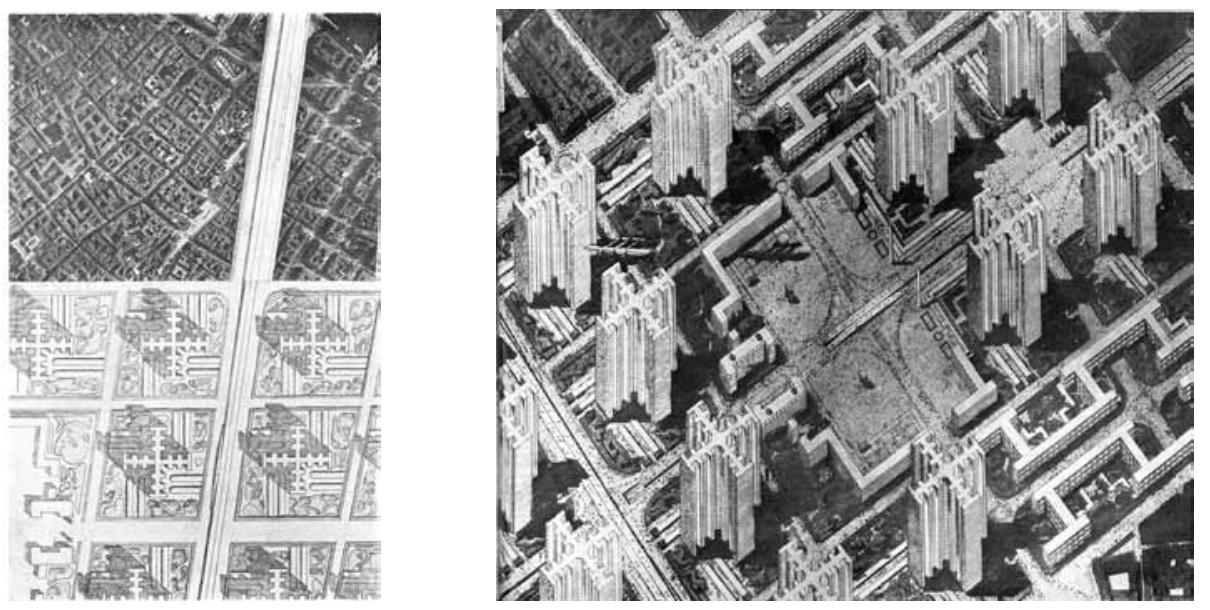

Figs 8-9. Detailed fragment plan of Plan Voisin published in Urbanisme p. 273 And Axonometric view published in Gesamtes Werk 1929, p. 116 @ FLC-ADAGP

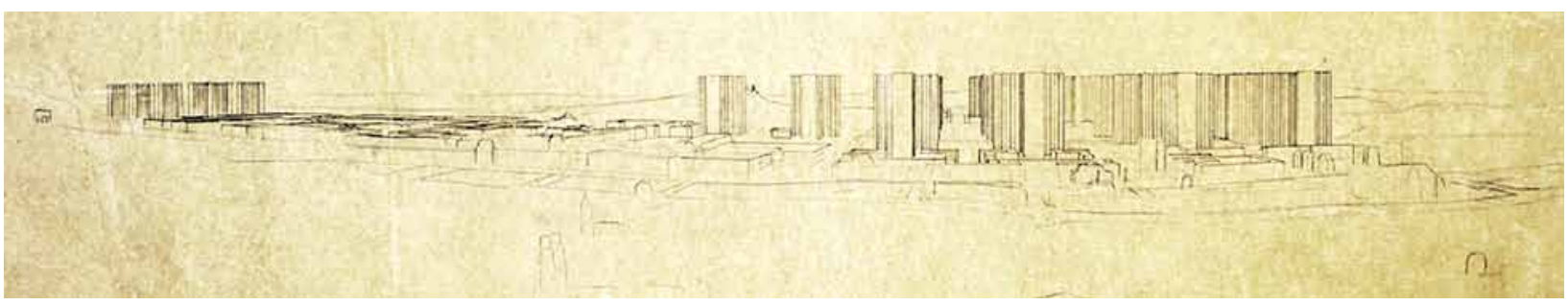

Fig. 10. Sketch for diorama of Plan Voisin. FLC31003 @ FLC-ADAGP

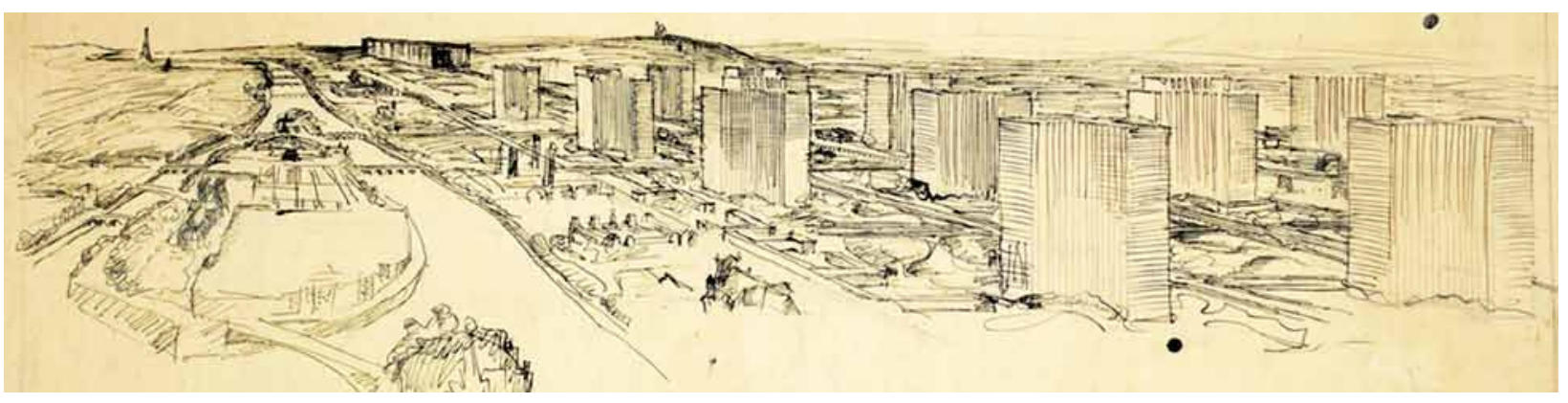

Fig. 11. Aerial perspective of Plan Voisin. FLC 29721 @ FLC-ADAGP

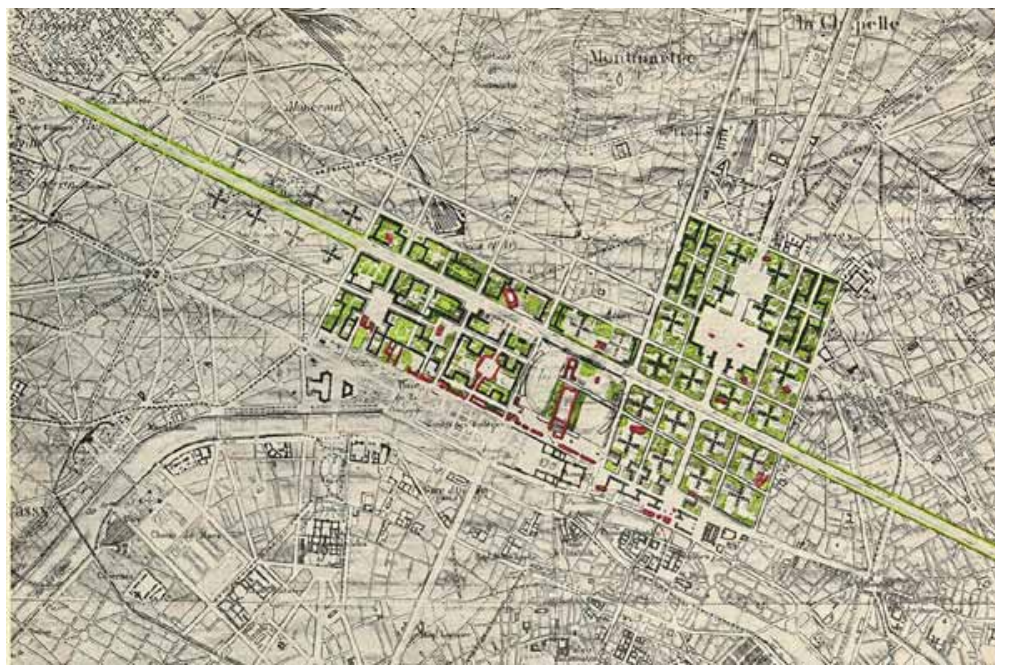

Fig. 12. General floor plan of "Plan Voisin". Version published in Science et Industrie 1926, p. 30. ๑ FLC-ADAGP

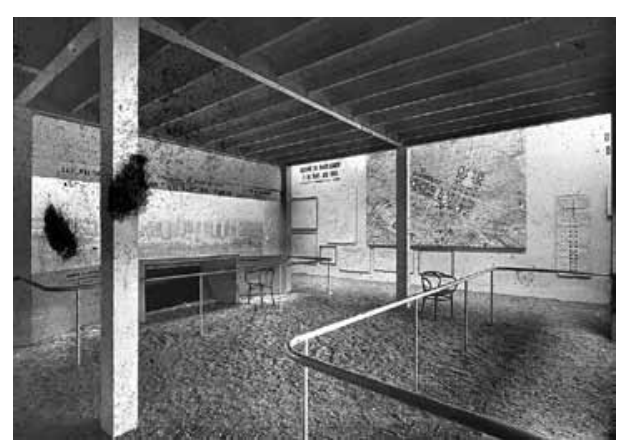

Fig. 13. Photography of exhibition taken inside of Esprit Nouveau pavilion 1925. FLC-ADAGP 
The use of color in the floor plan helps to distinguish the new buildings (in black) from the large green zones gained by the city. Additionally, red color indicates those patrimonial buildings that the Voisin Plan maintains. Unfortunately, the size of the plan in the publications does not allow detailing easily the buildings. In some cases, the red marks end up becoming not readable blots. Surely this would not happen when looking directly at the plan in its original dimensions.
Some photographs give an idea about those dimensions (Fig. 13).

An exercise of reconstructing the original plan can determine, by following the color marks, the exact location of the patrimonial buildings preserved. In some cases there are isolated buildings and in others, fragments that form longitudinal bars of adjoining houses. For a better visualization of the cases, the images are shown in sectors of the plan:

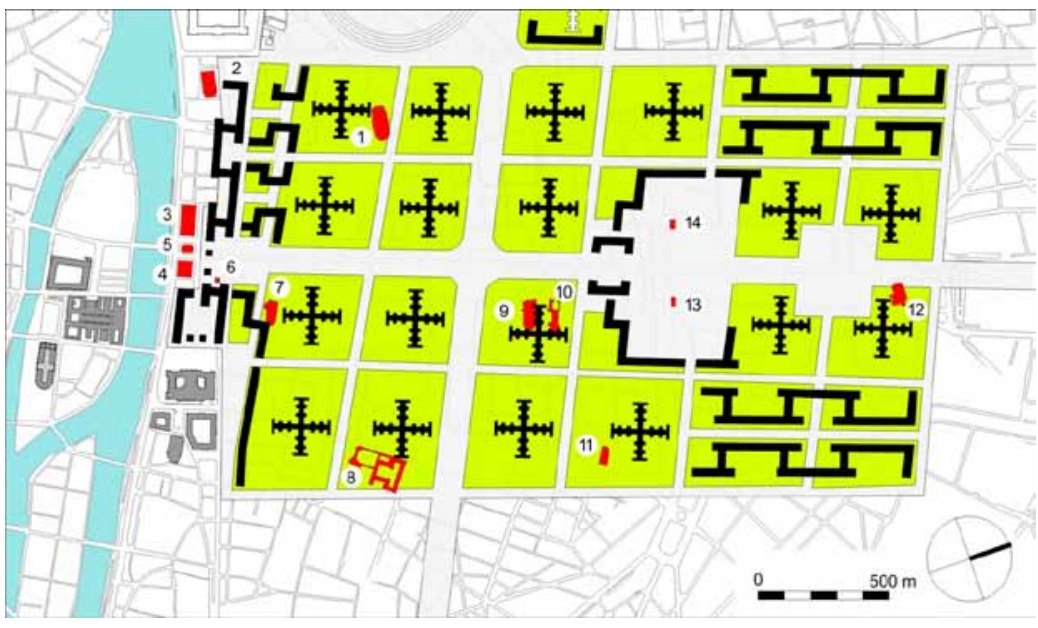

Fig. 14. Sector A (Business Center)

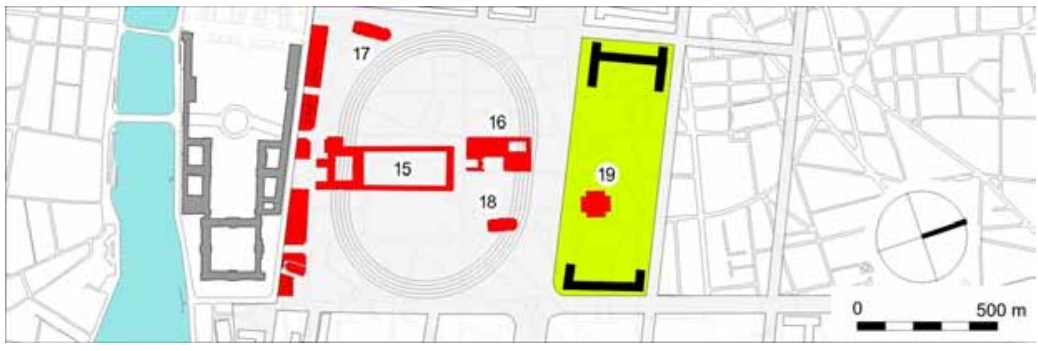

Fig. 15. Sector B (Central Station)

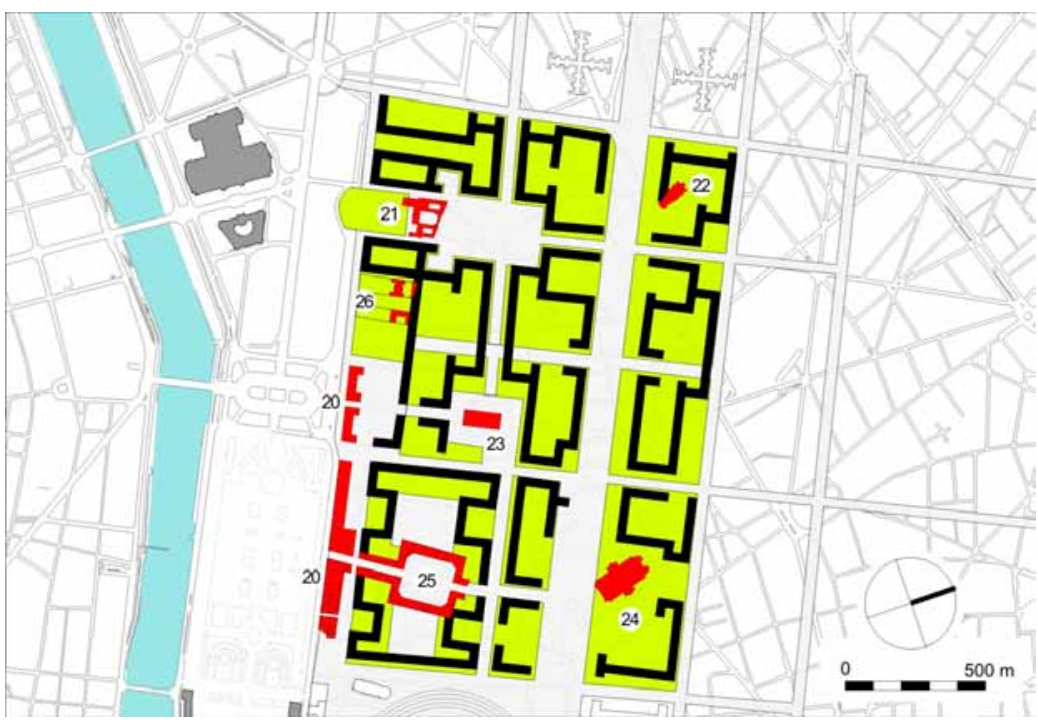

Fig. 16. Sector C (residential area)
Sector A (Business Center)

1. Church of Saint-Eustache (15321632);

2. Church of Saint-Germainl'Auxerrois (15th-century);

3. Théâtre du Châtelet (1860-1862);

4. Théâtre de la Ville (1860-1862);

5. Fontaine du Palmier (1806);

6. Saint-Jacques Tower (1509-1525);

7. Church of Saint Merri (1500-1550);

8. The Hôtel de Soubise - Museum of National Archives (1375);

9. Church of Saint-Nicolas des Champs (1420-1668);

10. Priory of Saint-Martin-des-Champs (1135-1862);

11. Church of Sainte-Élisabeth-deHongrie (1628-1646);

12. Church of Saint-Laurent (14291870);

13. Porte Saint-Martin (1674);

14. Porte Saint Denis (1672);

Sector B (Central Station)

15. The Palais-Royal (1633-1639) with theatres;

16. Sainte-Geneviève Library (18381850) - Richelieu quadrilateral;

17. Church of Saint Roch (1722);

18. Basilica of Notre-Dame des Victoires (1629-1740);

19. Brongniart Palace (The Paris Bourse) (1808-1829);

Sector C (residential area)

20. Buildings that make up the front of Rivoli street;

21. The Élysée Palace (1718-1722);

22. Church of Saint Augustine (1868);

23. La Madeleine Church (1828);

24. The Palais Garnier (1861-1875);

25. Place Vendôme (1699), Castiglione street and rue de la Paix;

26. United States and UK embassies. 
The rest of the documents of the Plan tend to lose precision regarding the preserved patrimony and it focus the attention in the business center over the other sectors. For example, the montage of page 110 of the CEuvre Complète (Fig. 8) that illustrate the fragment of the floor plan on a larger scale, should have included Saint-Nicolas des Champs and Saint-Martindes-Champs Churches, but these buildings have not been drawn. On the other hand, the photograph used for the montage includes an entire neighborhood (des Archives) which was demolish by the plan. Additionally its direction does not coincide with the floor plan. The montage, more than sticking to the proposal, the precision of the project, aims at making a contrast between the dense original weave much more spacious and green, and give an idea of the size of the skyscrapers

The axonometric drawing of the Plan (Fig. 9) that shows the great esplanade of the business center, should have to contain several of the patrimonial buildings preserved that apparently have not been drawn. However, there is a linear version of the drawing that allows appreciating the technical precision in the construction of this axonometric view (Fig. 17). The elevations have been done based on the floor plan, not only of the building in redents and the cruciform skyscrapers but also of the periphery blocks, with its registered divisions and the volumetric of the individual houses. The plan includes information about the patrimonial building, clearly defined by the letters that signal specific points; A- Porte Saint-Denis; B- Porte Saint-Martin; C- Old Priory of Saint-Martin des Champs; D- Saint Nicholas des Champs Church; E- Saint Elisabeth Church; FSaint Laurent Church; G- Paris Stock Market.

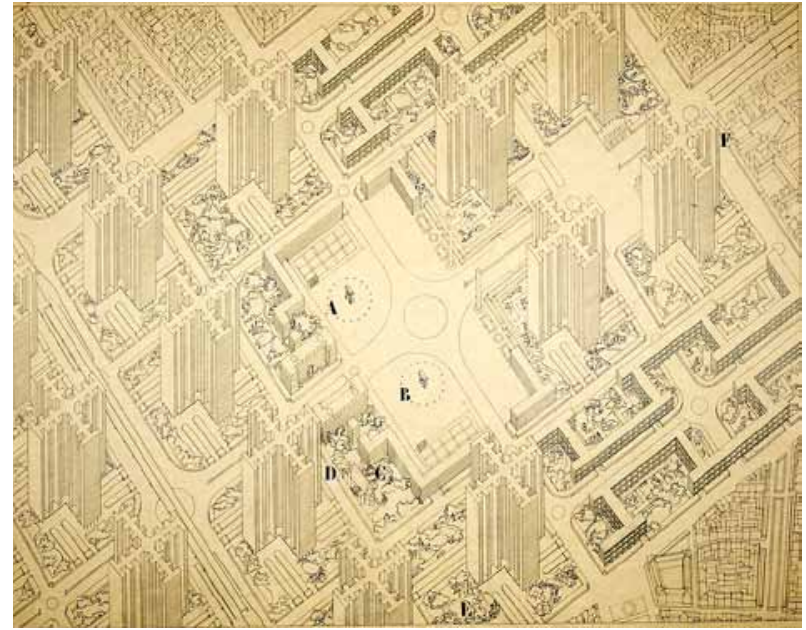

Fig. 17. Sketch for axonometric view. FLC29723 @ FLC-ADAGP

For the 1925 Exhibition and following the experience of 1922, Le Corbusier makes a diorama to be exhibited in the space in a roundabout annex to the Pavilion of l'Esprit Nouveau. The expectations on the impact of this diorama are high:

"For the Pavilion of the Esprit Nouveau [...] I painted a panorama whose aim was to make evident to the eye this new conception, so unfamiliar to us as yet. The panorama was most carefully executed and showed Paris as it is today, from Notre-Dame to the Étoile, including those monuments which are our imperishable heritage" (Le Corbusier 1925: 267).

Effectively, the approach of the drawing shows the location of the project within the city. It includes references such as the Montmartre hill, the Louvre Palace, Notre-Dame Cathedral and the riverbed of the Seine.
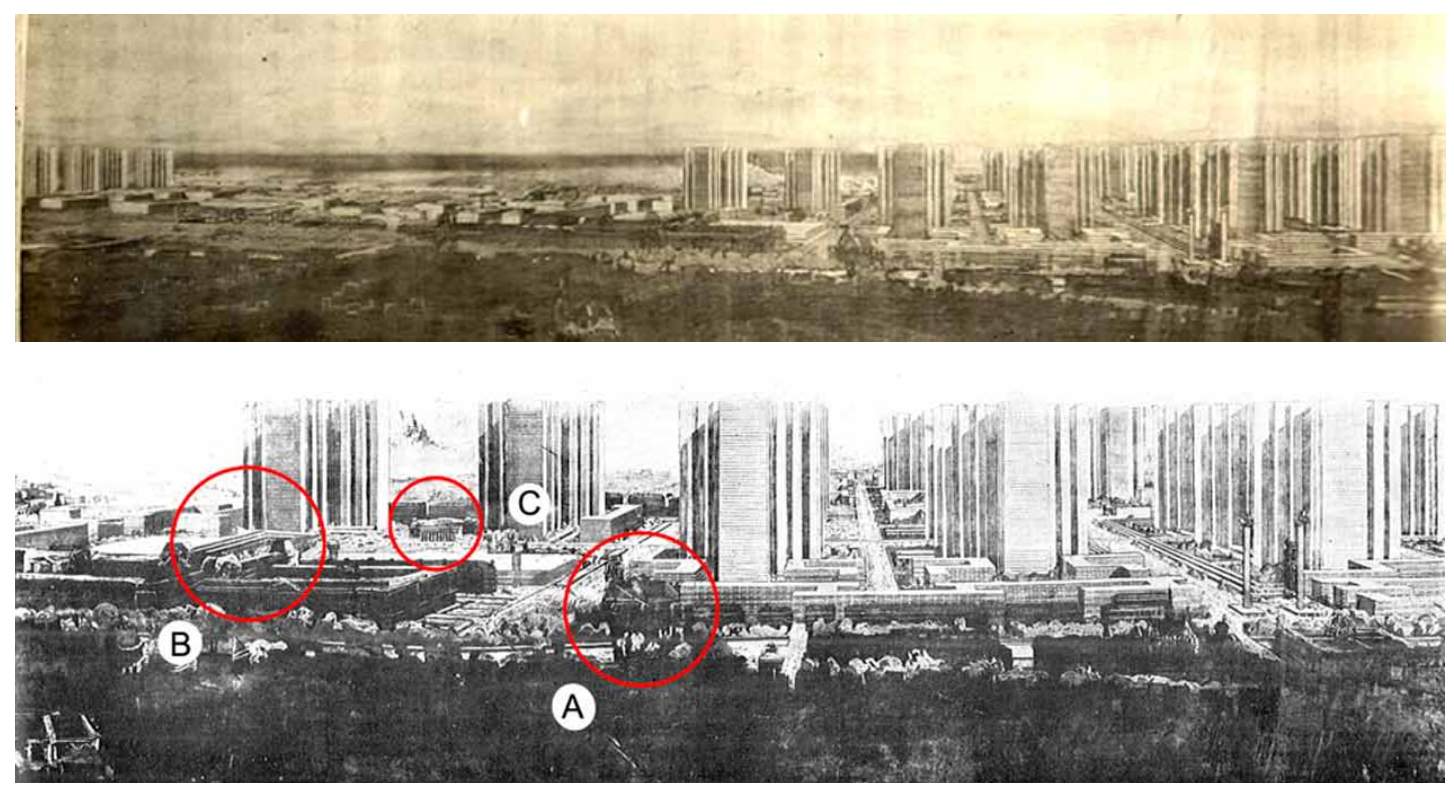

Figs 18a-18b Diorama of Plan Voisin and fragment. Version Urbanisme and Cuvre Complète. @ FLC-ADAGP 


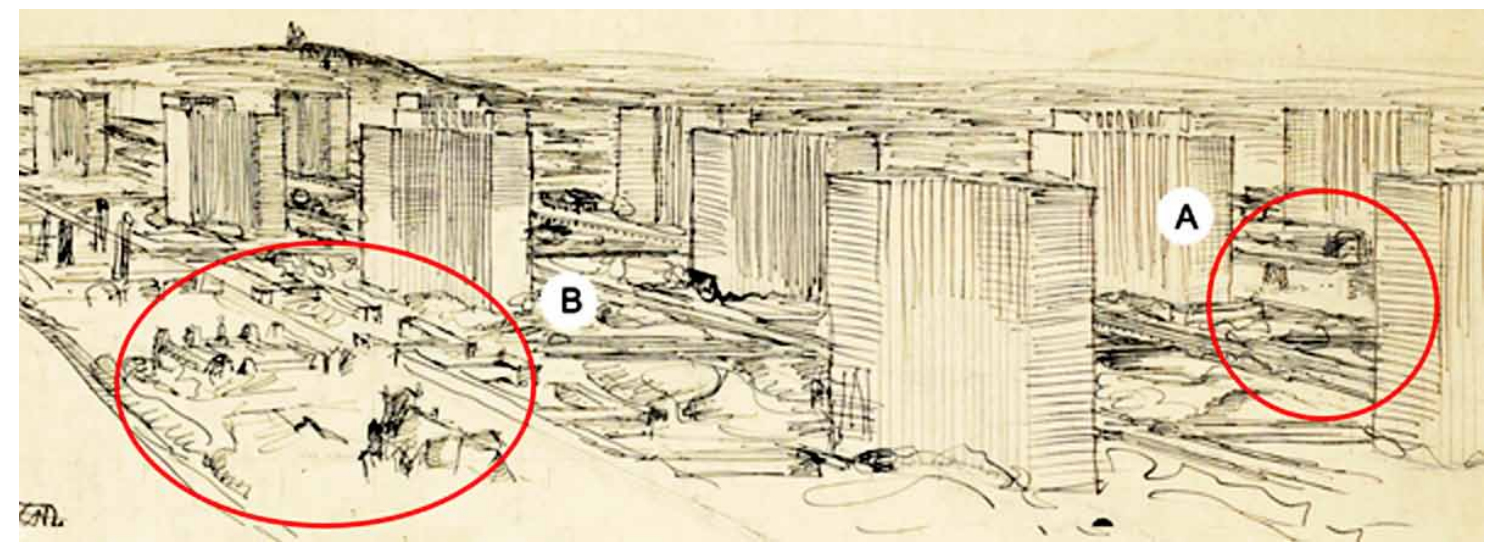

Fig. 19. Aerial perspective -fragment. FLC29721 @ FLC-ADAGP

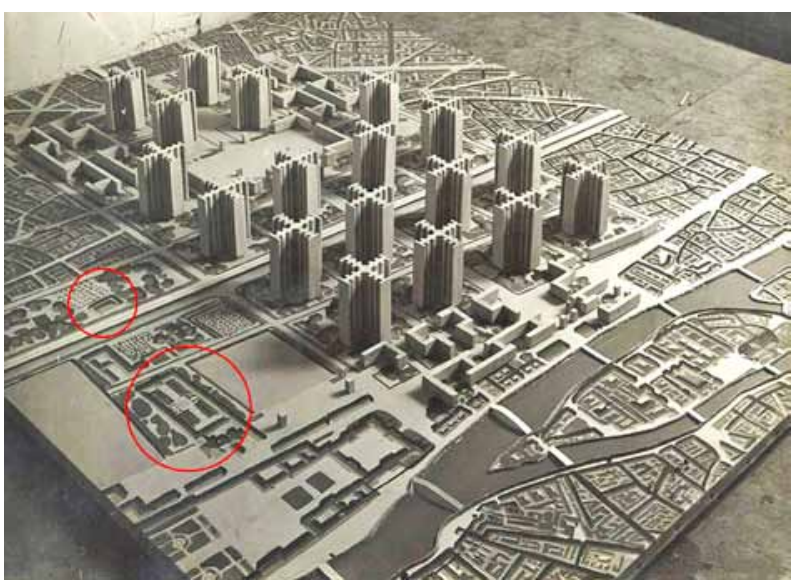

Fig. 20. Photograph of the model published in Ville Redieuse 1933. (c) FLC-ADAGP

The drawing done with the same technique of the first diorama (see Velásquez 2014) achieves an ample view of the entire proposal. With just one eyesight, it covers around 4800 meters amplitude, connecting the two extremes where the skyscrapers are concentrated. In the book Urbanisme, the drawing of the diorama occupies a double page (Fig. 18) while in the CEuvre Complète Le Corbusier publishes just a fragment that describes more clearly the zone of the closest skyscrapers (Fig. 19). In the drawing it is difficult to appreciate information about specific patrimonial buildings. However, in the foreground, and almost camouflaged by the buildings in redents, Saint-Germain-l'Auxerrois Church is drawn (A). On the other hand, the drawing attains a relatively detailed zone of the central station, together with the 18 skyscrapers of the business center. It is clear the prominence of the Palais Royal (B) and the Paris Bourse building $(\mathrm{C})$ flanked by the cruciform skyscrapers.

Showing his innate abilities for drawing, Le Corbusier draws an aerial view of the Voisin Plan (Figure 19). In this way he complements the information in the diorama. The drawing represents more cle- arly the implementation of the project, its scale and its relation with Paris. With the exception of both Porte Saint-Martin and Porte Saint Denis that can be seen on the extreme left (A), the drawing does not contain any other preserved building. It is a hint that cannot respond with much precision to reality. However, Le Corbusier has drawn two buildings in the foreground, located in the limits of the project that have been respected: the Paris City Hall (Hôtel de Ville) and SaintGervais-Saint-Protais Church (B).

There is a document, which was not done for the 1925 exhibition, but which is worth mentioning because it helps specify some important features of the Plan. The model is restricted to the sector of the business center and raises only the new buildings. Though there is no tridimensional presence of the preserved buildings, they appeared detailed by shadows and textures.

\section{Conclusions}

The study of the drawings of the Voisin Plan reveals that the so-called "Tabula rasa", relentless and radical for the affected zone of Paris, must be put into context. Le Corbusier makes concessions and in some cases, subtle reverences to a series of architectonic facts, under clearly patrimonial considerations. In Urbanisme he states:

"In this scheme the historical past, our common inheritance is respected. More than that, it is rescued. The persistence of the present state of crisis must otherwise lead rapidly to the destruction of that past. .... The "Voisin" scheme would isolate the whole of the ancient city and bring back peace and calm from SaintGervais to the Étoile. The districts of the Marais, the Archives, the Temple, etc., would be demolished. But the ancient churches would be preserved. They would stand surrounded by verdure; what could be more charming! And even if we must admit that their original environment has thus been transformed, we must agree 
that their present set- ting is not only an unreal one, but is also dreary and ugly" (Le Corbusier 1925: 272).

Effectively, a high percentage of all the preserved buildings correspond to churches. It is evident that Le Corbusier, a non-believer, concedes a high symbolic and patrimonial value to these churches. In the same way, it is curious the importance given to gothic or gothic style churches, due to his opinion, in some cases strongly critical towards this type of architecture (Le Corbusier 1925: 31-33).

On the other hand, the urban significance of the historic Saint-Martin y Saint Denis Portes has become more powerful because of their location within the great esplanade of the business center. In this way, these monuments become important protagonists.

But, independent from the isolated buildings, it is also undoubtable that for Le Corbusier that zone of Paris homes other types of piece of high patrimonial value. These are pieces of an intermediate scale, between the urban and the architectonic scale: the Palais Royal and Place Vendôme. In both cases the plan reserves relevant and carefully manipulated fragments. Contrary to the isolated and tiny buildings, these two pieces interact in a natural way with the rest of the buildings in redents. They have the same scale. The Palais Royal "reigns" in the central sector, floating over a great esplanade from where the Central station is accessed. And Place Vendôme conveniently outlined in its buildings, coexist harmoniously with the meandering buildings that frame it almost symmetrically.

Another fact that is important to highlight is a welldefined strategy in the front of Rivoli Street. There are entire bands of buildings preserved to conform a continuous façade. It is again, a conservation operation of a scale, relative to the rest of the project and a concession to other pieces of great value for Le Corbusier: The Louvre Museum and the Tuileries Gardens.

These pieces, together with others nearby as the Hôtel des Invalides and l'Ecole Militaire, on the west, and the Place les Vosgues on the east, add up to a series of groupings of large and intermediary scales, to which Le Corbusier has dedicated numerous studies (Figs 21-22).
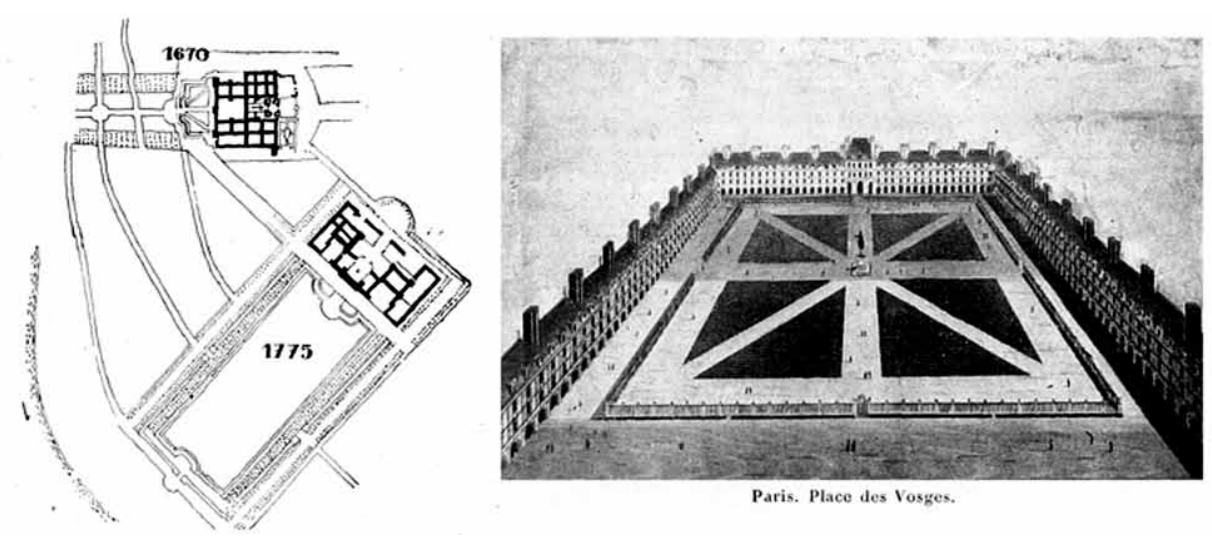

Fig. 21. Images of Hôtel des Invalides, I'Ecole Militaire and the Place les Vosgues in Urbanisme. @ FLC-ADAGP

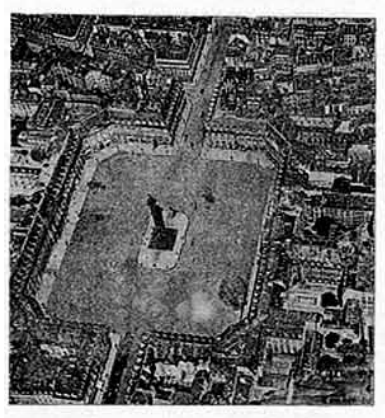

Paris, place Vendòme.

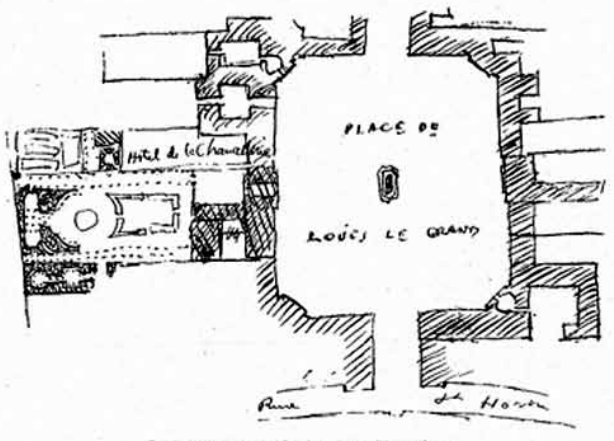

Le lotissement de la place Vendồne.

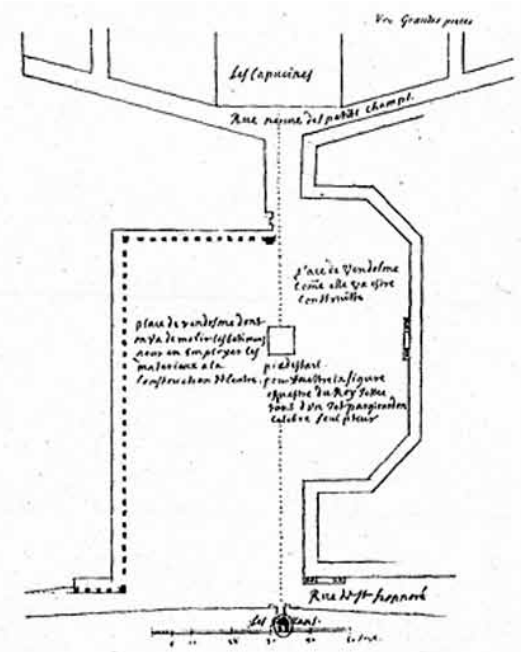

Fig. 22. Images of Place Vendôme in Urbanisme. @ FLC-ADAGP 


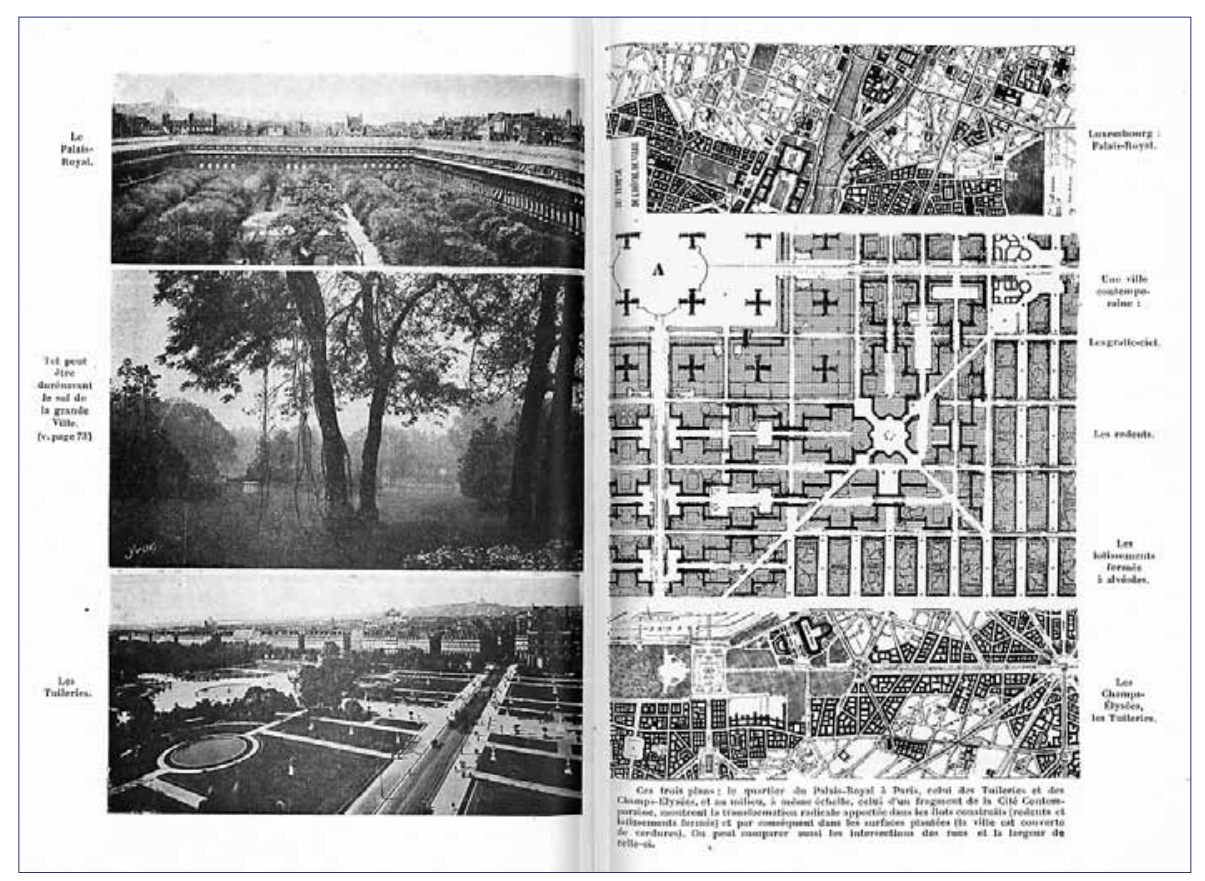

Fig. 23. graphic comparison in Urbanisme. () FLC-ADAGP
These are also cases he recurs to specify his ideas by means of graphic comparisons (see Velásquez 2013) (Fig. 24).

They are his referents. All these pieces are similar regarding their scale, their geometric clarity and the relation of its constructed mass with the empty space. These features help to understand the criteria on which the system of buildings in redents has been conceived, one of the main patterns of both the city for Three Million Inhabitants and the Voisin Plan.

It is, therefore, symptomatic the reading and assessment that Le Corbusier makes about the preexistences. The larger pieces, concentrated in sector $\mathrm{C}$ and mainly in $\mathrm{B}$, are the ones that best come into "dialogue" with an urbanism that has great voids defined by bars and an urban grid of great dimensions. On the other hand, there is a conservation criterion for isolated buildings of important historic and patrimonial value clustered in sector A that not always fit together with the great traces of the Plan. The isolated buildings, in some cases are confined or framed witjhin bars; in other cases they are separated to create contrast when its location or geometric design comes into clear conflict with the generic guidelines of the Plan. The most problematic cases are the Hôtel de Soubise, Saint-Nicolas des Champs Church, and the Saint-Martin-des-Champs Convent. Le Corbusier names all these buildings when he refers to their implantation "in the midst of the foliage". He is aware of the "transformation" (when one should really talk about total disappearance) of "its original frame" now replaced by a bucolic and romantic new landscape. He prefers to be considered naïve before applying a drastic operation by erasing these buildings from the
Plan. This will be a permanent problem with complex solutions in his following urban developments when he has to apply his ideas about existing urban grids and architectures ${ }^{1}$.

It must be reminded that the Plan Voisin is just a transitory state within a defining process that Xavier Monteys calls the theoretical models of urban intervention Le Corbusier's (Monteys 1996: 31). This process begins with the City of Three Million Inhabitants, a model that was implemented in specific plans such as Plan Voisin and La Ville Vert, becoming slowly the next great momentum that is the Ville Radieuse of 1932, and finally ending in the two models that come from the formulation of Les trois étabissements humaines (the city according to the $7 \mathrm{~V}$ rule and the linear industrial city). In this process the architectural elements experience a slow distilment that goes from the three types of buildings of the City for Three Million Inhabitants (cruciform skyscrapers, the iImmeuble-Villa or Lotissement fermés and the buildings in redents) up to the 6 types mentioned in 1946 (see Le Corbusier 1946: 131): Stepped, "Y"-shaped, Frontal, Sipnes, Staggered and Lens form. In this way, for example the cruciform buildings in the Plan Voisin have gained prominence and their use is not limited to the specific center. However, in spite of producing huge urban voids their rigorous location generates conflictive situations with

\footnotetext{
1 An example can be seen in the Plan d'Urbanisation for Bogotá, where Le Corbusier maintains a great part of the Carrera $7^{\mathrm{a}}$ as an urban scale entity and some isolated buildings of La Candelaria neighborhood (Le Corbusier 1946: 42-45)
} 
some existing churches. On the other hand the buildings in redents are used in some cases to frame isolated buildings, and though they are still highly conditioned by symmetric compositions they start gaining freedom tin their shape and layout that will be seen in future plans. In the last place the Immeuble-Villa buildings have been eliminated completely (and will no longer appear), while its urban function, is assumed by great historic cloisters: Le Palais Royal and La Plaza Vendôme.

Lastly, it is important to remember that radicalism of the Plan Voisin proposal is understood by Le Corbusier under two parameters: first, it can be part of the tradition of the city and second, it has a specific didactic objective.

The city has traditionally embraced some radical interventions that have ended up constituting important contributions for is improvement and magnificence. "If you look the" Plan Voisin "Paris looks to the west and southwest large plots of Louis XIV, Louis $\mathrm{XV}$, Napoleon Invalides, the Tuileries, Concorde, the Champs de Mars, L'Etoile. It is creating the spirit that has prevailed, which hit the confusion seen there. The new business is not listed as an anomaly; gives the impression of being in the tradition of following a normal progression" (Le Corbusier 1925).

On the other hand one tends to forget the advantage, consciously planned by le Corbusier, of the controversy. The Plan aimed at, above all, generating a debate around pressing issues of the contemporary city.

"The "Plan Voisin" has no intention of giving the exact solution of the case of central Paris. But it can serve to begin the discussion to a level in keeping with the period and raise the problem at scale. Opposes its principles to jumble of small reforms that every day we hope for our spirit" (Le Corbusier 1925).

In spite of this warning, Paris will be, for a long time, a constant motive for reflection for Le Corbusier (paradigmatic example of the Concentric-Radius city that ends up in tentacles) and its center a wonderful laboratory of ideas. Thus, following Plan Voisin of 1925 comes the more detailed version of the Plan in 1929 (Le Corbusier 1934: 91, 93) and the Paris Plan of 1937 that with the architectural development of the unhealthy Ilot No. 6 (see Le Corbusier 1938: 46, 53), can be considered the final version of Le Corbusier's intervention in the center of Paris. ${ }^{2}$

\footnotetext{
2 These two projects will be published again in volume IV of the Euvre Complète, under the title "1945 Plan de Paris" with new drawings. It is also important to mention the Project for the Cultural Center Orsay-Paris of 1961, which is a specific intervention in the Plan of 1937 (Le Corbusier 1965: 220-229).
}

\section{Disclosure statement}

I, Victor Hugo Velásquez, declare that this article does not compete for any personal, professional or financial interest from other parties.

\section{References}

Le Corbusier. 1925. Urbanisme. Paris: Crès.

Le Corbusier. 1926. Paris sera-t-il la première grande ville moderne du monde?, Science et industrie 154: 30-33.

Le Corbusier; Jeanneret, Pierre. 1929. Gesamtes Werk (Complete Works, vol.1). Zurich, Girsberger. Reprint 2006, Basel, Birkhäuser.

Le Corbusier. 1933. Ville Radieuse. Paris: Editions de l'Architecture d'aujourd'hui.

Le Corbusier. 1934. Euvre Complète. vol. 2

Le Corbusier. 1938. Euvre Complète. vol. 3

Le Corbusier. 1946. Euvre Complète. vol. 4

Le Corbuiser. 1965. Euvre Complète. vol. 7

Monteys, X. 1996. La gran máquina, la ciudad en Le Corbuiser. Barcelona: Ediciones del Serbal.

Rowe, C.; Koetter, F. 1978. The collage city. MIT Press.

Velásquez, V. 2012. EL LIBRO ABIERTO: Sistemas de representación arquitectónica en el libro Gesamtes Werk - Euvre Complète, Le Corbusier-Pierre Jeanneret, 1910-1929. Universitat Politécnica de Catalunya, Barcelona.

Velásquez, V. 2013. Graphic strategies in Le Corbusier's informative project in the 1920's: the case of Urbanisme, Dearq 12: 94-105.

Velásquez, V. 2014. The drawing of the contemporary city for 3 million inhabitants, elaborated by Le Corbusier and Pierre Jeanneret in 1922, EGA 23: 104-113.

von Moos, S. 2009. Le Corbusier: elements of synthesis. Rotterdam: Publishers.

\section{VICTOR HUGO VELÁSQUEZ}

Architect of the National University of Colombia and the Polytechnic University of Catalonia. Doctor in Visual Communication in Architecture and Design at the Polytechnic University of Catalonia. Assistant professor at the National University of Colombia. He developed and disseminated with the Architecture \& Manufacturing office via web the projects built in architectural concrete. He has been developing a research on architectural representation systems, its genesis, implementation and impact on modern architecture. 